\title{
G (5) \\ Effect of COVID-19 Pandemic on Anxiety in Rheumatology Patients Taking Immunosuppressive Drugs
}

\section{Tugba Izci Duran ( $\nabla$ drtugbaizciduran@gmail.com )}

Department of Internal Medicine, Division of Rheumatology, Medical Faculty, Ondokuz Mayıs University, Samsun, Turkey https://orcid.org/0000-0003-4428-9873

\section{Seyyid Bilal Acikgoz}

Department of Internal Medicine, Division of Rheumatology, Medical Faculty, Ondokuz Mayıs University, Samsun, Turkey https://orcid.org/0000-0002-4550-2712

\section{Cemal Gurbuz}

Department of Internal Medicine, Division of Rheumatology, Medical Faculty, Ondokuz Mayıs University, Samsun, Turkey https://orcid.org/0000-0002-7507-0666

\section{Aysegul Ucar}

Department of Internal Medicine, Division of Rheumatology, Medical Faculty, Ondokuz Mayıs University, Samsun, Turkey https://orcid.org/0000-0003-4125-3656

\section{Gokhan Yavuzbilge}

Department of Internal Medicine, Division of Rheumatology, Medical Faculty, Ondokuz Mayıs University, Samsun, Turkey https://orcid.org/0000-0002-8879-8859

\section{Metin Ozgen}

Department of Internal Medicine, Division of Rheumatology, Medical Faculty, Ondokuz Mayıs University, Samsun, Turkey https://orcid.org/0000-0002-6842-2918

\section{Research Article}

Keywords: anxiety, Beck anxiety inventory, biologic drug, COVID-19, immunosuppression, rheumatic and musculoskeletal diseases

Posted Date: July 23rd, 2020

DOl: https://doi.org/10.21203/rs.3.rs-35814/v2

License: () (1) This work is licensed under a Creative Commons Attribution 4.0 International License. Read Full License 


\section{Abstract}

Introduction: Coronavirus disease 2019 (COVID-19) pandemic is a public health emergency that is causing international concern. Patients with medical comorbidities are more likely to be infected and have a worse prognosis. The purpose of this study was to determine the prevalence of anxiety due to COVID-19 pandemic in patients with rheumatic and musculoskeletal diseases (RMDs) who used immunosuppressive drugs during the initial stage of the COVID-19 pandemic and to identify the risk and protective factors that cause anxiety.

Methods: A total of 145 patients with RMDs aged $\geq 18$ years who used regular immunosuppressive drugs and 95 healthy controls were included in the study. An anonymous survey comprising questions regarding the COVID-19 pandemic was used, and the Beck anxiety inventory (BAI) was used to measure the anxiety levels of participants. Additional information was collected such as demographic data, current RMDs, immunosuppressive drugs used, information and concerns about COVID-19, and the source of information about COVID-19.

Results: About $42.1 \%$ patients reported that the epidemic caused concern due to the drug they were using, and $33.8 \%$ rated their concerns as moderate and severe. The BAl scores of patients and healthy controls were 4 (0-52) and $3(0-18)$ respectively. According to the BAI scores, $16.5 \%$ patients had moderate to severe anxiety symptoms; and comparison of the groups showed that the anxiety level of the patient group was significantly higher $(38.6 \%$ vs. $18.9 \%, p=0.001)$. Female had more anxiety symptoms in both groups $(p<0.005)$. In addition, anxiety was lower in patients with higher education levels $(p=0.039)$.

Conclusion: It should be ensured that patients in the high-risk group are not provided false information, the patients are individually informed, and they trust the treatment team. Providing online or smartphonebased psychoeducation and psychological interventions may be considered for these patients with high anxiety levels.

\section{Introduction}

Coronavirus disease 2019 (COVID-19) was first described in Wuhan, China in December 2019 due to severe acute respiratory syndrome-coronavirus 2 (SARS-CoV-2) (1). Since then, the number of cases has been increasing exponentially, and the virus is spreading all over the world. COVID-19 was declared as a global health threat by the World Health Organization (WHO) on January 30, 2020, and it was recognized as a pandemic on March 11, $2020(2,3)$. This pandemic is the largest outbreak of atypical pneumonia since the outbreak of SARS in 2003. After the first outbreak, the total number of cases and deaths exceeded those of SARS (4). There is human-to-human transmission via respiratory droplets containing the virus (5). Patients with medical comorbidities are more likely to be infected and have worse prognosis (6). Mortality rate is estimated to be $5.7 \%$, and this rate ranges between $0.3 \%$ and $0.6 \%(7,8)$. Since the beginning of the pandemic, strict measures have been undertaken for the prevention of infection all over the world. After the first case was detected in Turkey on March 11, 2020, these measures have increased. 
Social isolation has been emphasized due to the exponential increase in the number of infected cases as well as the increase in mortality rates.

During infection outbreaks, a wide range of psychosocial effects are observed in people, and people experience the fear of falling ill or the fear of death as well as the feelings of desperation (9). Anxiety is also a common negative feeling experienced by the entire population during pandemics (10). During the COVID-19 pandemic, WHO made a number of recommendations regarding mental health and psychosocial issues (11). Most studies on this pandemic have focused on determining the epidemiology and clinical characteristics of infected patients, genomic characterization of the virus, and challenges of global health management $(5,6,12,13)$. During SARS and COVID-19 pandemics, studies were conducted to evaluate psychological responses of the general society $(14,15)$. COVID-19 pandemic has become a stressful factor, especially because this new viral infection does not have any vaccine and can be treated only symptomatically. The effect of anxiety caused by COVID-19 in patients with rheumatic musculoskeletal diseases (RMDs) who use immunosuppressive drugs is unknown. The European League Against Rheumatism (EULAR) has reported that patients who use immunosuppressive [e.g. biological drugs, JAK inhibitors (targeted synthetic disease modifier drugs-tsDMARD), and steroid and conventional DMARDs (csDMARDs like methotrexate, hydroxychloroquine)] drugs during the current pandemic of COVID-19 may have various issues as well as anxiety (16). However, there is no research on the psychological effect of COVID-19 in patients with RMDs who use immunosuppressive drugs. The purpose of this study is to determine the prevalence of anxiety due to COVID-19 pandemic in patients with RMDs who were using immunosuppressive drugs immediately after the first case of COVID-19 was reported in Turkey and WHO declared the pandemic and to identify the risk and protective factors that contribute to the anxiety.

\section{Materials And Methods}

\section{Participants}

After 16 days of the first case of COVID-19 seen in Turkey at $11^{\text {th }}$ of March, 2020, this study was started and patients who admitted to outpatient clinic at February 2020 was determined. 145 patients aged $\geq 18$ years with RMDs who were regularly using immunosuppressive drugs (biological drugs, tsDMARDs, and csDMARDs) and in remission under treatment were included. Patients who did not visit outpatient clinic regularly, who did not take their medication regularly, who had active disease, who had mental retardation, who had difficulty understanding the questions, who did not volunteer to participate in the study, who used antidepressant drugs, and who were $<18$ years of age were excluded in the study. The study comprised 145 patients who had immunosuppressive therapy including 26 with familial Mediterranean fever (FMF), 33 with rheumatoid arthritis (RA), 31 with connective tissue disease (CTD), 25 with spondyloarthropathy (SpA), and 30 with vasculitis. Further, 95 healthy individuals without a known chronic disease or regular drug use and similar to patient group were included in the control group.

\section{Study design}


In this observational and cross-sectional clinical study, self-reported questionnaires were used. Previous studies on the psychological effects of SARS and influenza outbreaks were reviewed (17-19). Accordingly, an anonymous survey was developed that included additional questions about the COVID-19 pandemic. The structured survey comprised questions covering several areas as follows: (1) demographic data; (2) information and concerns about COVID-19; (3) where the information about COVID-19 was obtained; (4) knowledge of current number of COVID-19 cases; (5) anxiety due to the immunosuppressive drugs used by the participant; and (6) diagnosis of COVID-19 in the participant or someone they knew. Anxiety was measured using a clinical survey and scoring system which was conducted the Turkish validity and reliability study by Ulusoy et al (20). The questionnaire was filled with the patients one to one and the data were collected. The questionnaire was filled anonymously by answering all questions by 145 patients and 95 healthy controls.

\section{Demographic data and social characteristics}

The demographic data and social characteristics of the study participants included age, gender, education and marital status, and the number of children they had. The professional and business data included titles and information regarding the institutions they worked for. In addition, existing chronic diseases of patients and immunosuppressive drugs used were recorded.

\section{Beck Anxiety Inventory (BAI)}

The BAI was developed by Beck et al. to assess the degree of anxiety symptoms in an individual (21). BAI is a self-reporting questionnaire comprising 21 items; each item is rated between 0 and 3 points and gives a total score of 0 to 63 points. The total score from the scale indicates the degree of anxiety of the individual. Those with BAI scores of $0-7,8-15,16-25$, and $26-63$ are classified to have "no anxiety symptoms," "mild symptoms," "medium symptoms", and "severe symptoms," respectively and were grouped into no anxiety symptoms (0-7 points) and the presence of anxiety symptoms (8-63 points) based on the BAl scores (21).

\section{Statistical analysis}

The Statistical Package for Social Sciences version 22.0 software was used to evaluate the data. Descriptive statistical data are expressed as frequency (percentage), number and mean \pm standard deviation, or median (min-max). The distribution properties of the numeric variables were evaluated by Kolmogorov-Smirnov test. Independent-samples t-test was used for intergroup comparisons of numeric variables with normal distribution, and Mann-Whitney's $U$ test was used for variables without normal distribution. The estimates of the strengths of associations were demonstrated by the odds ratio (OR) with a $95 \%$ confidence interval $(\mathrm{Cl})$. Categorical data were evaluated using chi-square test. A P-value of $<0.05$ was considered statistically significant.

\section{Results}


A total of 240 individuals, including 145 patients and 95 healthy controls, meeting the study criteria were included in the study by filling the survey. Mean age of the patient and control groups were $40.41 \pm 13.51$ and $42.34 \pm 10.07$ years, respectively. No difference was observed between the groups in terms of age and gender $(p=0.183)$. No patient was diagnosed with COVID-19 in both groups. The demographic and clinical characteristics are shown in Table 1.

Table 1. Demographic and clinical characteristics of the patient and control groups

\begin{tabular}{|c|c|c|c|}
\hline \multicolumn{2}{|c|}{ Study Parameters } & Patient Group ( $\mathrm{n}=145)$ & $\begin{array}{c}\text { Control Group } \\
(\mathrm{n}=95)\end{array}$ \\
\hline \multicolumn{2}{|l|}{ Female / Male (n) } & $85 / 60$ & $47 / 48$ \\
\hline \multicolumn{2}{|c|}{ Age, mean \pm standard deviation } & $40,41 \pm 13,51$ & $42,34 \pm 10,07$ \\
\hline \multirow[t]{2}{*}{ Marital status, n (\%) } & Married & $102(70.3)$ & $81(85.3)$ \\
\hline & Single & $43(29.7)$ & $14(14.7)$ \\
\hline \multirow[t]{2}{*}{ Status as a parent, $\mathrm{n}(\%)$} & Has & $105(72.4)$ & 75 (78.9) \\
\hline & No children & $40(27.6)$ & $20(21.1)$ \\
\hline \multirow[t]{5}{*}{ Number of children, $\mathrm{n}(\%)$} & 0 & $40(27.6)$ & $20(21.1)$ \\
\hline & 1 & $18(12.4)$ & $23(24.2)$ \\
\hline & 2 & $44(30.3)$ & $38(40.0)$ \\
\hline & 3 & $35(24.1)$ & $7(7.4)$ \\
\hline & $>3$ & $8(5.5)$ & $7(7.4)$ \\
\hline \multirow{4}{*}{$\begin{array}{l}\text { Educational } \\
\text { attainment, n (\%) }\end{array}$} & Lower secondary school & $77(53.1)$ & $24(25.3)$ \\
\hline & Upper secondary school & $41(28.3)$ & $17(17.9)$ \\
\hline & University-Bachelors & $27(18.6)$ & $34(35.8)$ \\
\hline & University- Masters/Doctorate & - & $20(21.1)$ \\
\hline \multirow[t]{6}{*}{ Occupation, n (\%) } & Officer & $19(13.1)$ & $29(30.5)$ \\
\hline & Worker & $34(23.4)$ & 11 (11.6) \\
\hline & Manager & $3(2.1)$ & $15(15.8)$ \\
\hline & Retired & 17 (11.7) & $18(18.9)$ \\
\hline & Student & $17(11.7)$ & $1(1.1)$ \\
\hline & Unemployed & $55(37.9)$ & $21(22.1)$ \\
\hline \multirow{5}{*}{$\begin{array}{l}\text { Working institution, } \\
\text { n (\%) }\end{array}$} & Private sector & $31(21.4)$ & $20(21.1)$ \\
\hline & Public & 23 (15.9) & 29 (30.5) \\
\hline & Self-employment & $5(3.4)$ & $6(6.3)$ \\
\hline & Retired & $14(9.7)$ & $18(18.9)$ \\
\hline & Unemployed & $72(49.7)$ & $22(23.2)$ \\
\hline \multirow[t]{8}{*}{ Medication used, n (\%) } & Anti TNF & $39(26.9)$ & - \\
\hline & Tocilizumab & $6(4.1)$ & - \\
\hline & Tofacitinib & $7(4.8)$ & - \\
\hline & Anti IL-1 & $26(17.9)$ & - \\
\hline & Cyclophosphamide & $3(2.1)$ & - \\
\hline & Rituximab & $2(1.4)$ & - \\
\hline & csDMARD & $60(41.4)$ & - \\
\hline & Anti IL-17 & $2(1.4)$ & - \\
\hline
\end{tabular}

RA: Rheumatoid Arthritis; SpA: Spondyloarthropathy; FMF: Familal Mediterranean fever; CTD: Connective Tissue Disease; COVID-19: Coronavirus disease 2019, Anti TNF: Anti tumor necrosis factor; Anti IL-1: Anti interleukin-1; Anti IL-17: Anti interleukin 17; csDMARD: Conventional Disease Modifying Anti-Rheumatic Drugs;

The concerns of patients and healthy controls about COVID-19, information about current number of COVID-19 cases, anxiety about COVID-19 due to the immunosuppressive drugs used by them, BAI scores, and anxiety levels were evaluated. Overall, $76.6 \%$ patients reported that they were up-to-date with the 
current number of COVID-19 cases, and 63.4\% reported that their knowledge levels about COVID-19 were intermediate. Patients stated that they learned COVID-19 information on television (82.8\%) and the internet (13.1\%); $42.1 \%$ reported that the pandemic caused concern due to the drug they used; and $33.8 \%$ rated their concerns as moderate and severe. The BAI scores of the patients and healthy controls were 4 (0-52) and 3 (0-18), respectively. According to the BAl scores, $16.5 \%$ patients had moderate to severe anxiety symptoms. The concern levels and BAI scores of both groups are shown in Table 2.

Table 2. Anxiety levels and Beck anxiety evnanter scores of patients and healthy controls

\begin{tabular}{|c|c|c|c|}
\hline \multicolumn{2}{|l|}{ Study Parameters } & $\begin{array}{l}\text { Patient Group } \\
(\mathrm{n}=145)\end{array}$ & $\begin{array}{c}\text { Control Group } \\
(\mathrm{n}=95)\end{array}$ \\
\hline $\begin{array}{l}\text { COVID-19 case information, } \\
\mathrm{n}(\%)\end{array}$ & $\begin{array}{l}\text { Yes } \\
\text { No }\end{array}$ & $\begin{array}{l}111(76.6) \\
34(23.4)\end{array}$ & $\begin{array}{l}88(92.6) \\
7(7.4)\end{array}$ \\
\hline COVID-19 knowledge level, n (\%) & $\begin{array}{l}\text { No knowledge } \\
\text { Intermediate } \\
\text { Totally dominated }\end{array}$ & $\begin{array}{l}8(5.5) \\
92(63.4) \\
45(31.0)\end{array}$ & $\begin{array}{l}2(2.1) \\
39(41.1) \\
54(56.8)\end{array}$ \\
\hline The main source of COVID-19 information, $\mathrm{n}(\%)$ & $\begin{array}{l}\text { Television } \\
\text { Internet } \\
\text { Newspaper } \\
\text { No Information }\end{array}$ & $\begin{array}{l}120(82.8) \\
19(13.1) \\
4(2.8) \\
2(1.4)\end{array}$ & $\begin{array}{l}58(61.1) \\
26 / 27.4) \\
11(11.6) \\
-\end{array}$ \\
\hline $\begin{array}{l}\text { Does the medicine you use cause concern, } \\
\mathrm{n}(\%)\end{array}$ & $\begin{array}{l}\text { Yes } \\
\text { No } \\
\text { Undecided }\end{array}$ & $\begin{array}{l}61(42.1) \\
72(49.7) \\
12(8.3)\end{array}$ & $\begin{array}{l}- \\
- \\
-\end{array}$ \\
\hline How much do you worry about medication, $\mathrm{n}(\%)$ & $\begin{array}{l}\text { No worries } \\
\text { Mild } \\
\text { Moderate } \\
\text { Severe }\end{array}$ & $\begin{array}{l}79(54.5) \\
17(11.7) \\
30(20.7) \\
19(13.1)\end{array}$ & $\begin{array}{l}- \\
- \\
-\end{array}$ \\
\hline \multicolumn{2}{|l|}{ Beck Anxiety Inventory score, median (min-max) } & $4(0-52)$ & $3(0-18)$ \\
\hline Anxiety symptoms level, n (\%) & $\begin{array}{l}\text { No anxiety symptoms } \\
\text { Mild } \\
\text { Moderate } \\
\text { Severe }\end{array}$ & $\begin{array}{l}89(61.4) \\
32(22.1) \\
17(11.7) \\
7(4.8)\end{array}$ & $\begin{array}{l}77(81.1) \\
17(17.9) \\
1(1.1) \\
-\end{array}$ \\
\hline Anxiety symptom status, n (\%) & $\begin{array}{l}\text { No } \\
\text { Yes }\end{array}$ & $\begin{array}{l}89(61.4) \\
56(38.6)\end{array}$ & $\begin{array}{l}77(81.1) \\
18(18.9)\end{array}$ \\
\hline
\end{tabular}

RA: Rheumatoid Arthritis; SpA: Spondyloarthropathy; FMF: Familal Mediterranean fever; CTD: Connective Tissue Disease; COVID-19: Coronavirus disease 2019,

Both groups were evaluated in terms of the factors affecting anxiety states within the groups. Upon examining the affecting factors such as gender, age, marital status, number of children, occupation, institution, biological medicine used, and DMARDs, female were found to have more anxiety symptoms in both the groups. In addition, anxiety symptoms was lower in patients with higher education levels $(p=0.039)$. When comparing COVID-19 knowledge in terms of communication tools and occupational groups between the two groups, no significant difference was observed. Factors affecting anxiety in both groups are shown in Table 3.

Table 3. Comparison of factors affecting anxiety in patient and control groups 


\begin{tabular}{|c|c|c|c|c|c|c|c|}
\hline & \multicolumn{3}{|c|}{ Patient Group } & \multicolumn{3}{|c|}{ Control Group } \\
\hline & & \multicolumn{2}{|c|}{ Anxiety status } & \multirow[t]{2}{*}{$\mathrm{p}$} & \multicolumn{2}{|c|}{ Anxiety status } & \multirow[t]{2}{*}{$p$} \\
\hline & & Presence & Absence & & Presence & Absence & \\
\hline Gender,n (\%) & $\begin{array}{l}\text { Female } \\
\text { Male }\end{array}$ & $\begin{array}{l}39(45.9) \\
17(28.3)\end{array}$ & $\begin{array}{l}46(54.1) \\
43(71.7)\end{array}$ & ,033 & $\begin{array}{l}15(31.9) \\
3(6.3)\end{array}$ & $\begin{array}{l}32(68.1) \\
45(93.8)\end{array}$ & 001 \\
\hline Age, median (min-max) & & $\begin{array}{l}38(20- \\
82)\end{array}$ & $\begin{array}{l}43(18- \\
70)\end{array}$ & 480 & $\begin{array}{l}43(26- \\
60)\end{array}$ & $\begin{array}{l}42(28- \\
62)\end{array}$ & 890 \\
\hline Marital status, n (\%) & $\begin{array}{l}\text { Married } \\
\text { Single }\end{array}$ & $\begin{array}{l}38(37.3) \\
18(41.9)\end{array}$ & $\begin{array}{l}64(62.7) \\
25(58.1)\end{array}$ & 603 & $\begin{array}{l}17(21) \\
1(7.1)\end{array}$ & $\begin{array}{l}64(79) \\
13(92.9)\end{array}$ & 294 \\
\hline $\begin{array}{l}\text { Status as a parent, } \\
\mathrm{n}(\%)\end{array}$ & $\begin{array}{l}\text { Has } \\
\text { No children }\end{array}$ & $\begin{array}{l}38(36.2) \\
18(45)\end{array}$ & $\begin{array}{l}67(63.8) \\
22(55)\end{array}$ & 330 & $\begin{array}{l}14(18.7) \\
4(20)\end{array}$ & $\begin{array}{l}61(81.3) \\
16(80)\end{array}$ & 1,00 \\
\hline Number of children, $\mathrm{n}$ (\%) & $\begin{array}{l}0 \\
1 \\
2 \\
3 \\
>3\end{array}$ & $\begin{array}{l}18(45) \\
6(33.3) \\
17(38.6) \\
11(31.4) \\
4(50) \\
\end{array}$ & $\begin{array}{l}22(55) \\
12(66.7) \\
27(61.4) \\
24(68.6) \\
4(50) \\
\end{array}$ & 717 & $\begin{array}{l}4(20) \\
1(4.3) \\
10(26.3) \\
3(42.9) \\
0(0) \\
\end{array}$ & $\begin{array}{l}16(80) \\
22(95.7) \\
28(73.7) \\
4(57.1) \\
7(100) \\
\end{array}$ & 054 \\
\hline $\begin{array}{l}\text { Educational attainment, } \mathrm{n} \\
\text { (\%) }\end{array}$ & $\begin{array}{l}\text { Lower secondary } \\
\text { school } \\
\text { Upper secondary } \\
\text { school } \\
\text { University-Bachelors } \\
\text { University- } \\
\text { Masters/Doctorate }\end{array}$ & $\begin{array}{l}31(40.3) \\
20(48.8) \\
5(18.5) \\
-\end{array}$ & $\begin{array}{l}46(59.7) \\
21(51.2) \\
22(81.5) \\
-\end{array}$ & 039 & $\begin{array}{l}9(37.5) \\
2(11.8) \\
3(8.8) \\
4(20)\end{array}$ & $\begin{array}{l}15(62.5) \\
15(88.2) \\
31(91.2) \\
16(80)\end{array}$ & 053 \\
\hline Occupation, n (\%) & $\begin{array}{l}\text { Officer } \\
\text { Worker } \\
\text { Manager } \\
\text { Retired } \\
\text { Student } \\
\text { Unemployed }\end{array}$ & $\begin{array}{l}5(26.3) \\
13(38.2) \\
0(0) \\
7(41.2) \\
6(35.3) \\
25(38.6) \\
\end{array}$ & $\begin{array}{l}14(73.7) \\
21(61.8) \\
3(100) \\
10(58.8) \\
11(64.7) \\
30(54.5) \\
\end{array}$ & ,505 & $\begin{array}{l}4(13.8) \\
2(18.2) \\
1(6.7) \\
4(22.2) \\
1(100) \\
6(28.6) \\
\end{array}$ & $\begin{array}{l}25(86.2) \\
9(81.8) \\
14(93.3) \\
14(77.8) \\
0(0) \\
15(71.4) \\
\end{array}$ & 240 \\
\hline Working institution, n (\%) & $\begin{array}{l}\text { Private sector } \\
\text { Public } \\
\text { Self-employment } \\
\text { Retired } \\
\text { Unemployed } \\
\end{array}$ & $\begin{array}{l}12(38.7) \\
7(30.4) \\
1(20) \\
5(35.7) \\
31(43.1) \\
\end{array}$ & $\begin{array}{l}19(61.3) \\
16(69.6) \\
4(80) \\
9(64.3) \\
41(56.9) \\
\end{array}$ & 730 & $\begin{array}{l}1(5) \\
4(13.8) \\
2(33.3) \\
4(22.2) \\
7(31.8) \\
\end{array}$ & $\begin{array}{l}19(95) \\
25(86.2) \\
4(66.7) \\
14(77.8) \\
15(68.2) \\
\end{array}$ & 140 \\
\hline $\begin{array}{l}\text { COVID-19 case } \\
\text { information, } \mathrm{n}(\%)\end{array}$ & $\begin{array}{l}\text { Yes } \\
\text { No }\end{array}$ & $\begin{array}{l}41(36.9) \\
15(44.1)\end{array}$ & $\begin{array}{l}70(63.1) \\
19(55.9)\end{array}$ & 452 & $\begin{array}{l}17(19.3) \\
1(14.3)\end{array}$ & $\begin{array}{l}71(80.7) \\
6(85.7)\end{array}$ & 1,00 \\
\hline Drug,n (\%) & $\begin{array}{l}\text { Biologic drug + } \\
\text { tsDMARD } \\
\text { csDMARD }\end{array}$ & $\begin{array}{l}38(44.7) \\
18(30)\end{array}$ & $\begin{array}{l}47(55.3) \\
42(70)\end{array}$ & 073 & - & - & - \\
\hline $\begin{array}{l}\text { The main source of COVID- } \\
19 \text { information, } n(\%)\end{array}$ & $\begin{array}{l}\text { Television } \\
\text { Newspaper } \\
\text { Internet }\end{array}$ & $\begin{array}{l}47(39.2) \\
0(0) \\
8(42.1)\end{array}$ & $\begin{array}{l}73(60.8) \\
4(100) \\
11(57.9)\end{array}$ & 361 & $\begin{array}{l}14(24.6) \\
1(10) \\
3(10.7)\end{array}$ & $\begin{array}{l}43(75.4) \\
9(90) \\
25(89.3)\end{array}$ & 231 \\
\hline
\end{tabular}

RA: Rheumatoid Arthritis; SpA: Spondyloarthropathy; FMF: Familal Mediterranean fever; CTD: Connective Tissue Disease; COVID-19: Coronavirus disease 2019, csDMARD: Conventional Disease Modifying AntiRheumatic Drugs; tsDMARD: Targeted Synthetic Disease Modifying Anti-Rheumatic Drugs

Multivariate logistic regression analysis includes the level of education and gender factor found significant in univariate analysis. In this analysis, it was determined that male gender $(O R=0.460,95 \%$ 
$\mathrm{Cl}=0.221-0.958, \mathrm{p}=0.038)$ and university graduation $(\mathrm{OR}=0.234,95 \% \mathrm{Cl}=0.073-0.749, \mathrm{p}=0.014)$ are protective factors for anxiety in the patient group.

A total of $38.6 \%$ patients taking immunosuppressive drugs had anxiety and $18.9 \%$ in the control group had anxiety. Compared to the control group, anxiety in the patient group was significantly higher $(p=0.001)$. Although there was no significant difference in the anxiety levels and anxiety conditions of patients receiving biological drugs + tsDMARDs and csDMARDs as immunosuppressive drugs, patients taking biological drugs + tsDMARDs had more anxiety $(p=0.056$; Table 4$)$.

Table 4. Comparison of csDMARD group and biologic drug + tsDMARD group

\begin{tabular}{l|l|c|c|c}
\hline \multicolumn{2}{l|}{} & csDMARD & Biologic Drug + tsDMARD & P \\
\hline Anxiety Level, & No anxiety & $42(47.2)$ & $47(52.8)$ & 0.056 \\
n (\%) & Mild & $13(40.6)$ & $19(59.4)$ & \\
& Moderate & $5(8.3)$ & $12(70.6)$ & \\
& Severe & - & $7(100.0)$ & \\
\hline Anxiety, n (\%) & Yes & $18(32.1)$ & $38(67.9)$ & 0.073 \\
& No & $42(47.2)$ & $47(52.8)$ & \\
\hline
\end{tabular}

CSDMARD: Conventional Disease Modifying Anti-Rheumatic Drugs; tsDMARD: Targeted Synthetic Disease Modifying Anti-Rheumatic Drugs

\section{Discussion}

In this study, the prevalence of anxiety caused by COVID-19 pandemic and the risk and protective factors contributing to psychological stress in patients with RMDs who were using immunosuppressive drugs were investigated. Female sex was a risk factor for anxiety in the patients taking immunosuppressive drugs as well as in the control group. In addition, anxiety levels of patients who took immunosuppressive drugs were significantly higher than the control group, whereas anxiety was lower in those with higher education levels. Based on the BAI scores, $16.5 \%$ patients showed moderate to severe anxiety symptoms.

COVID-2019 is a pandemic and pandemics have various psychological effects on humans, including anxiety (22). During the influenza epidemic (influenza A H1N1v), approximately $10 \%$ and $30 \%$ of the population had high or severe anxiety (17). In a study conducted on the general population on the COVID19 pandemic in China, 53.8\% participants rated the psychological effect of the pandemic as moderate or severe, and $28.8 \%$ reported moderate to severe anxiety symptoms (15).

Sensational popular media titles, lack of information, and incorrect information have shown to increase the health concerns and phobias (23). Television (82.8\%) and the Internet (13.1\%) were the primary information channels during the initial stage of the COVID-19 pandemic. Most participants $(76.6 \%)$ were aware about the number of cases, advice on prevention, and warnings for those with chronic diseases. However, it is believed that this information, the accuracy of which is controversial, can lead to an increase in patient anxiety levels. 
A guideline has stated that it is important to medically and psychologically prepare the health systems and general public if widespread transmission occurs during a pandemic (24), and it is recommended to identify high-risk groups based on the sociodemographic information for early psychological intervention (15). The sociodemographic data in this study have shown that women who take immunosuppressive drugs have a higher level of anxiety. This result supports the extensive epidemiological studies reporting that women are at a higher risk of anxiety (25-27).

In a study conducted on the general population in China, it was found that students experienced a higher level of anxiety and psychological impact due to the pandemic (15). Schools of all levels have been indefinitely closed in Turkey as well as the rest of the world. In this study, there were no significant differences in terms of anxiety based on occupational groups including students. During pandemics, educational authorities should develop online portals and web-based applications for courses and other teaching activities (28). Although schools are closed in Turkey, many teaching activities continue online. As the younger population is more familiar with smartphone applications (29), they are able to continue their education. It is believed that this may be the reason why high levels of anxiety have not been detected in the younger individuals.

A recent study in China found that the general population without formal education was more likely to be depressed during the pandemic (15). In another study that evaluated population-based psychological morbidity after the SARS epidemic, there was a significant correlation between education level and psychiatric morbidity, and it was recommended to divide the population into sections based on the level of education to increase crisis communication (10). In this study, anxiety was lower in those with higher education levels. Therefore, it may be recommended to provide audio-visual information with simple language, when required, to support patients based on their education levels during the pandemic.

In this study, anxiety was found in $38.6 \%$ patients. The prevalence of anxiety in patients with RA, SpA, vasculitis, FMF, and connective tissue disease were $39.4 \%, 16 \%, 36.7 \%, 65.4 \%$, and $35.5 \%$, respectively. A study that evaluated anxiety disorder in patients with rheumatic disease, anxiety was reported in $44.4 \%$ patients. The prevalence of anxiety in patients with RA, primary Sjögren syndrome, systemic lupus erythematosus, and Behçet syndrome were reported to be $52 \%, 50 \%, 41 \%$, and $38 \%$, respectively (30). The prevalence of anxiety in the SpA group was similar to the previous study (31), whereas the prevalence of anxiety in the FMF patient group was higher than the other groups. This suggests that FMF patient group may have been more affected by social isolation caused by the quarantine process due to younger age and being more active. Similarly, in studies that compared patients with inflammatory rheumatic diseases with healthy controls, anxiety was higher in the patient group (32-39).

In this study, the prevalence of anxiety was $18.9 \%$ in the control group, and there was a significant difference in anxiety levels between the patient and controls groups. In pre-pandemic studies, the prevalence of anxiety in healthy controls is significantly lower than that found in this study $(6.6 \%-9.6 \%)$ $(31,35,36)$. Although the control group had increased anxiety levels, the difference was significant, suggesting that our patients had high anxiety. It may be recommended that health authorities consider 
providing online or smartphone-based psychoeducation and psychological interventions to reduce the risk of virus infection via face-to-face treatment. In addition, they should be informed individually by the clinic where they are followed, and it should be ensured that they trust the treatment team.

This study has several limitations. Given the inability to meet face-to-face and time sensitivity of the COVID-19 pandemic, data were collected by contacting patients on the phone. The reported anxiety levels may not always correspond to the assessment by mental health professionals. Similarly, patients may have given socially desirable responses regarding their anxiety levels. Finally, a patient was diagnosed with COVID-19 and had no relatives around her/him. Therefore, surveys may have been conducted early. Despite the above limitations, this study, which was conducted on patients with inflammatory RMDs who were using immunosuppressive drugs 2 weeks after the appearance of COVID-19 in Turkey, was considered to be the first that evaluated the effects of pandemic on anxiety. As the COVID-19 pandemic continues to spread, our results are expected to provide recommendations on the development of psychological support for patients in the risk group who are taking immunosuppressive drugs and in priority areas in Turkey and in other countries affected by the pandemic.

\section{Conclusion}

This observational cross-sectional study evaluated anxiety caused by immunosuppressive drugs used by patients diagnosed with RMDs during the COVID-19 pandemic in Turkey. Neither the participants nor their relatives encountered COVID-19 infection; however, a high level of anxiety was found in patients. Anxiety in female patients and patients who were using immunosuppressive drugs was higher. In this process, it should be ensured that these patients in the high-risk group are not provided false information, the patients are informed individually, and they trust the treatment team. Providing online or smartphonebased psychoeducation and psychological interventions may be considered for these patients with high anxiety.

\section{Declarations}

\section{Availability of data and materials}

The datasets used and/or analysed during the current study are available from the corresponding author on reasonable request.

\section{Ethical approval}

This study was conducted in accordance with the Helsinki Declaration. All participants were informed and their consent was obtained. The study was approved by the local ethics committee and the Ministry of Health (Approval number: 2020/132).

\section{Declaration of conflicting interests}


The authors declared no conflicts of interest with respect to the authorship and/or publication of this article.

\section{Contributions}

All authors have contributed equally to the development of the manuscript. All authors read and approved the final manuscript.

\section{Corresponding author}

Correspondence to Tugba Izci Duran.

\section{Acknowledgements}

Not applicable.

\section{Funding}

The authors received no financial support for the research and/or authorship of this article.

\section{Abbreviations}

Anti TNF: Anti Tumor Necrosis Factor

Anti IL-1: Anti Interleukin-1

Anti IL-17: Anti Interleukin-17

BAl: Beck Anxiety Inventory

COVID-19: Coronavirus Disease 2019

csDMARD: Conventional Disease Modifying Anti-Rheumatic Drugs

CTD: Connective Tissue Disease

EULAR: European League Against Rheumatism

FMF: Familal Mediterranean Fever

RA: Rheumatoid Arthritis

RMDs: Rheumatic Musculoskeletal Diseases

SARS-CoV-2: Severe Acute Respiratory Syndrome-Coronavirus 2

SpA: Spondyloarthropathy 
tsDMARD: Targeted Synthetic Disease Modifying Anti-Rheumatic Drugs

WHO: World Health Organization

\section{References}

1. Song J, Kang S, Choi SW, Seo KW, Lee S, So MW, et al. Coronavirus Disease 19 (COVID-19) complicated with pneumonia in a patient with rheumatoid arthritis receiving conventional diseasemodifying antirheumatic drugs. Rheumatol Int. 2020;40(6):991-5.

2. Organization WH. Coronavirus disease 2019 ( COVID-19): situation report, 51. 2020.

3. Wang C, Horby PW, Hayden FG, Gao GF. A novel coronavirus outbreak of global health concern. Lancet. 2020;395(10223):470-3.

4. Hawryluck L, Gold WL, Robinson S, Pogorski S, Galea S, Styra R. SARS control and psychological effects of quarantine, Toronto, Canada. Emerg Infect Dis. 2004;10(7):1206-12.

5. Huang C, Wang Y, Li X, Ren L, Zhao J, Hu Y, et al. Clinical features of patients infected with 2019 novel coronavirus in Wuhan, China. The Lancet. 2020;395(10223):497-506.

6. Chen N, Zhou M, Dong X, Qu J, Gong F, Han Y, et al. Epidemiological and clinical characteristics of 99 cases of 2019 novel coronavirus pneumonia in Wuhan, China: a descriptive study. The Lancet. 2020;395(10223):507-13.

7. Nishiura H, Kobayashi T, Yang Y, Hayashi K, Miyama T, Kinoshita R, et al. The rate of underascertainment of novel coronavirus (2019-nCoV) infection: Estimation using Japanese passengers data on evacuation flights. Multidisciplinary Digital Publishing Institute; 2020.

8. Baud D, Qi X, Nielsen-Saines K, Musso D, Pomar L, Favre G. Real estimates of mortality following COVID-19 infection. The Lancet Infectious Diseases. 2020.

9. Hall RC, Hall RC, Chapman MJ. The 1995 Kikwit Ebola outbreak: lessons hospitals and physicians can apply to future viral epidemics. Gen Hosp Psychiatry. 2008;30(5):446-52.

10. Peng EY, Lee MB, Tsai ST, Yang CC, Morisky DE, Tsai LT, et al. Population-based post-crisis psychological distress: an example from the SARS outbreak in Taiwan. J Formos Med Assoc. 2010;109(7):524-32.

11. Organization WH. Mental health and psychosocial considerations during the COVID-19 outbreak, 18 March 2020. World Health Organization; 2020.

12. Lu R, Zhao X, Li J, Niu P, Yang B, Wu H, et al. Genomic characterisation and epidemiology of 2019 novel coronavirus: implications for virus origins and receptor binding. The Lancet. 2020;395(10224):565-74.

13. Rubin GJ, Wessely S. The psychological effects of quarantining a city. Bmj. 2020;368.

14. Sim K, Chan YH, Chong PN, Chua HC, Soon SW. Psychosocial and coping responses within the community health care setting towards a national outbreak of an infectious disease. Journal of psychosomatic research. 2010;68(2):195-202. 
15. Wang C, Pan R, Wan X, Tan Y, Xu L, Ho CS, et al. Immediate psychological responses and associated factors during the initial stage of the 2019 coronavirus disease (COVID-19) epidemic among the general population in china. International Journal of Environmental Research and Public Health. 2020;17(5):1729.

16. Rheumatism TELA. EULAR Guidance for patients COVID-19 outbreak 2020 [Available from: https://www.eular.org/eular_guidance_for_patients_covid19_outbreak.cfm.

17. Rubin GJ, Potts HW, Michie S. The impact of communications about swine flu (influenza A H1N1v) on public responses to the outbreak: results from 36 national telephone surveys in the UK. Health Technol Assess. 2010;14(34):183-266.

18. Leung GM, Lam TH, Ho LM, Ho SY, Chan BH, Wong IO, et al. The impact of community psychological responses on outbreak control for severe acute respiratory syndrome in Hong Kong. J Epidemiol Community Health. 2003;57(11):857-63.

19. Leung GM, Quah S, Ho LM, Ho SY, Hedley AJ, Lee HP, et al. Community psycho-behavioural surveillance and related impact on outbreak control in Hong Kong and Singapore during the SARS epidemic. Hong Kong Med J. 2009;15 Suppl 9:30-4.

20. Ulusoy M, Sahin NH, Erkmen H. The Beck anxiety inventory: psychometric properties. Journal of cognitive psychotherapy. 1998;12(2):163-72.

21. Beck AT, Epstein N, Brown G, Steer RA. An inventory for measuring clinical anxiety: psychometric properties. Journal of consulting and clinical psychology. 1988;56(6):893.

22. Taylor S. The Psychology of Pandemics: Preparing for the Next Global Outbreak of Infectious Disease: Cambridge Scholars Publishing; 2019.

23. Taylor S, Asmundson GJ. Treating health anxiety: A cognitive-behavioral approach: Guilford Press; 2004.

24. Patel A, Jernigan DB. Initial Public Health Response and Interim Clinical Guidance for the 2019 Novel Coronavirus Outbreak - United States, December 31, 2019-February 4, 2020. MMWR Morb Mortal Wkly Rep. 2020;69(5):140-6.

25. Remes 0 , Brayne C, Van Der Linde R, Lafortune L. A systematic review of reviews on the prevalence of anxiety disorders in adult populations. Brain and behavior. 2016;6(7):e00497.

26. Somers JM, Goldner EM, Waraich P, Hsu L. Prevalence and incidence studies of anxiety disorders: a systematic review of the literature. Can J Psychiatry. 2006;51(2):100-13.

27. Steel Z, Marnane C, Iranpour C, Chey T, Jackson JW, Patel V, et al. The global prevalence of common mental disorders: a systematic review and meta-analysis 1980-2013. Int J Epidemiol. 2014;43(2):476-93.

28. Zhang MW, Ho CS, Ho R. Methodology of development and students' perceptions of a psychiatry educational smartphone application. Technology and Health Care. 2014;22(6):847-55.

29. Do TTT, Le MD, Van Nguyen T, Tran BX, Le HT, Nguyen HD, et al. Receptiveness and preferences of health-related smartphone applications among Vietnamese youth and young adults. BMC Public Health. 2018;18(1):764. 
30. Lisitsyna TA, Veltishchev DY, Seravina OF, Kovalevskaya OB, Starovoytova MN, Desinova OV, et al. Comparative analysis of anxiety-depressive spectrum disorders in patients with rheumatic diseases. Ter Arkh. 2018;90(5):30-7.

31. Baysal O, Durmus B, Ersoy Y, Altay Z, Senel K, Nas K, et al. Relationship between psychological status and disease activity and quality of life in ankylosing spondylitis. Rheumatol Int. 2011;31(6):795-800.

32. Yilmaz N, Can M, Oner FA, Kalfa M, Emmungil H, Karadag O, et al. Impaired quality of life, disability and mental health in Takayasu's arteritis. Rheumatology (Oxford). 2013;52(10):1898-904.

33. Karlidag R, Unal S, Evereklioglu C, Sipahi B, Er H, Yologlu S. Stressful life events, anxiety, depression and coping mechanisms in patients with Behcet's disease. J Eur Acad Dermatol Venereol. 2003;17(6):670-5.

34. VanDyke MM, Parker JC, Smarr KL, Hewett JE, Johnson GE, Slaughter JR, et al. Anxiety in rheumatoid arthritis. Arthritis Rheum. 2004;51(3):408-12.

35. Isik A, Koca SS, Ozturk A, Mermi O. Anxiety and depression in patients with rheumatoid arthritis. Clin Rheumatol. 2007;26(6):872-8.

36. Xu X, Shen B, Zhang A, Liu J, Da Z, Liu H, et al. Anxiety and depression correlate with disease and quality-of-life parameters in Chinese patients with ankylosing spondylitis. Patient preference and adherence. 2016;10:879.

37. Deger SM, Ozturk MA, Demirag MD, Aslan S, Goker B, Haznedaroglu S, et al. Health-related quality of life and its associations with mood condition in familial Mediterranean fever patients. Rheumatol Int. 2011;31(5):623-8.

38. Yilmaz-Oner S, Oner C, Dogukan FM, Moses TF, Demir K, Tekayev N, et al. Anxiety and depression predict quality of life in Turkish patients with systemic lupus erythematosus. Clin Exp Rheumatol. 2015;33(3):360-5.

39. Oláh C, Kardos Z, Andrejkovics M, Szarka E, Hodosi K, Domján A, et al. Assessment of cognitive function in female rheumatoid arthritis patients: associations with cerebrovascular pathology, depression and anxiety. Rheumatol Int. 2020;40(4):529-40. 